\title{
Mobilization of Arsenic during One-Year Incubations of Grey Aquifer Sands from Araihazar, Bangladesh
}

\author{
Kathleen A. Radloff ${ }^{1,}{ }^{*}$, Zhongqi Cheng ${ }^{2}$, Mohammad W. Rahman ${ }^{3}$, Kazi M. Ahmed ${ }^{3}$, Brian J. \\ Mailloux ${ }^{4}$, Andrew R. Juhl' ${ }^{2}$, Peter Schlosser ${ }^{1,2}$, and Alexander van Geen ${ }^{2}$ \\ 1Dept. of Earth and Environmental Engineering, Columbia University, New York, NY 10025 \\ 2Lamont-Doherty Earth Observatory of Columbia University, Palisades, NY 10964 \\ 3Department of Geology, University of Dhaka, Dhaka, Bangladesh \\ 4Barnard College, Columbia University, New York, NY 10025
}

\begin{abstract}
Elevated As concentrations in shallow groundwater pose a major health threat in Bangladesh and similarly affected countries, yet there is little consensus on the mechanism of As release to groundwater or how it might be influenced by human activities. In this study, the rate of As release was measured directly with incubations lasting 11 months, using sediment and groundwater collected simultaneously in Bangladesh and maintained under anaerobic conditions throughout. Groundwater and grey sediment were collected as diluted slurries between 5 and $38 \mathrm{~m}$ depth, a range over which ambient groundwater As concentrations increased from 20 to $100 \mu \mathrm{g} \mathrm{L}{ }^{-1}$. Arsenic was released to groundwater in slurries from 5 and $12 \mathrm{~m}$ depth at a relatively constant rate of $21 \pm 4(2 \sigma)$ and $23 \pm$ $6 \mu \mathrm{g} \mathrm{As} \mathrm{kg}^{-1} \mathrm{yr}^{-1}$, respectively. Amendment with a modest level of acetate increased the rate of As release only at $12 \mathrm{~m}\left(82 \pm 18 \mu \mathrm{g} \mathrm{kg}^{-1} \mathrm{yr}^{-1}\right)$. Although the groundwater As concentration was initially highest at $38 \mathrm{~m}$ depth, no release of As was observed. These results indicate that the spatial distribution of dissolved As in Bangladesh and local rates of release to groundwater are not necessarily linked. Iron release during the incubations did not occur concurrently with As release, providing further confirmation that the two processes are not directly coupled. Small periodic additions of oxygen suppressed the release of As from sediments at all three depths, which supports the notion that anoxia is a prerequisite for accumulation of As in Bangladesh groundwater.
\end{abstract}

\section{Introduction}

An estimated 100 million people are exposed to elevated levels of As by drinking untreated groundwater throughout South Asia. In Bangladesh, one-third of all wells did not meet the Bangladesh drinking water standard of $50 \mu \mathrm{g} \mathrm{L}-1$ and one-half did not meet the World Health Organization guideline of $10 \mu \mathrm{g} \mathrm{L}^{-1}$ before mitigation efforts began (1). It is widely believed that elevated As concentrations in anoxic groundwater reflect desorption from Fe oxyhydroxide surfaces as Fe(III) is converted to dissolved Fe(II) or mixed Fe(II/III) surfaces (2,3). Extensive field surveys show, however, that the relationship between dissolved As and Fe concentrations

*Corresponding author: E-mail: kar2108@ columbia.edu Phone: 845-365-8412; Fax: 845-365-8154.

Supporting Information.

Dissolved concentrations of Fe, As, Mn, S, P and the major cations ( $\mathrm{Na}, \mathrm{Mg}, \mathrm{K}$ and $\mathrm{Ca}$ ) are reported for both the site profiles and the incubations. Fe and As sediment concentrations from the $\mathrm{HCl}$ and phosphate extractions are given. The values used for the Langmuir calculations of increased surface site availability are reported.

Brief. Release of As to anaerobic groundwater was remarkably steady over an extended period, only moderately enhanced by additions of organic substrate, and decoupled from release of Fe. 
is highly scattered in Bangladesh, although their concentrations in the sediment are highly correlated $(2,4)$. More recently, detrital sulfide phases have been proposed as an alternative shallow source of As that is mobilized through redox cycling in near-surface sediments in Bangladesh (5). The importance of Fe reduction has been further brought into question by observations in model systems of significant As mobilization with only moderate reduction of Fe(III) minerals and before significant releases of Fe(II) into solution (6-9). The role of As reduction per se for mobilization is also still unclear. Studies using natural sediments and model sediments inoculated with Fe- or As-reducing microbes have shown enhancement of mobilization when arsenate is reduced to As(III) $(6,10)$. But other studies have shown that As (III) is not necessarily more mobile than $\mathrm{As}(\mathrm{V})$ under all environmental conditions, particularly when phosphate is present $(11,12)$.

It is generally accepted that microbial activity influences As release, either through direct interactions or indirectly via Fe oxyhydroxides, although the nature of this relationship remains poorly understood $(2,13)$. Organic substrate additions in both field and incubation studies, meant to enhance microbially mediated As mobilization have shown mixed results $(10,14$, 15). In addition, the extent to which large substrate additions are representative of the process of As release under natural conditions is unclear since major shifts in the population of dominant groups of the microbial community in response to substrate additions have been observed (15). The provocative notion that irrigation pumping might have enhanced the supply of organic substrate to shallow aquifers in recent decades, hereby triggering the release of As, has also been put forth $(14,16)$.

The motivation for the present study is that some of these unsettled issues could be addressed by knowing the rate at which As is released in aquifers in different geological settings. Previous incubations using natural aquifer sediment have provided valuable mechanistic insights, but intentional or unintentional manipulations of the material have hampered the extrapolation of measured rates to natural conditions $(5,10,15,17)$. A distinguishing feature of the incubations described here is that groundwater and sediment were collected simultaneously using a device coined the needle-sampler, placed immediately under anaerobic conditions in the field, rapidly transported to the laboratory and maintained under such conditions for the 11-month duration of the experiment (18).

\section{Materials and Methods}

\section{Site Description}

The sampling site $\left(90.6^{\circ} \mathrm{E}, 23.8^{\circ} \mathrm{N}\right)$ is at the center of an expanse of rice paddies in Araihazar upazila, $30 \mathrm{~km}$ east of Dhaka. Grey aquifer sediments extend to a depth of $48 \mathrm{~m}$ at this location. The radiocarbon age of two wood fragments recovered during drilling of the site in January $2005\left(6970 \pm 45\right.$ and $7180 \pm 55{ }^{14} \mathrm{C}$ yr at 40 and $44 \mathrm{~m}$ depth, respectively) confirm that the aquifer is of Holocene age (19). The generally sandy section of grey material is interrupted by a clay layer between 27 and $34 \mathrm{~m}$ depth (Figure 1). Numerous mechanized irrigation wells are distributed across the surrounding rice paddies and draw water through screens that span the entire shallow grey aquifer (20).

A set of monitoring wells (site F in (21)) located $1 \mathrm{~km}$ northwest of the sampling site shows a gradual increase in As concentrations in groundwater of the area from $<10 \mu \mathrm{g} \mathrm{L}^{-1}$ at $6 \mathrm{~m}$ depth to $\sim 50 \mu \mathrm{g} \mathrm{L}-1$ at $15 \mathrm{~m}$ depth (21). Over the same depth range, groundwater dating using the ${ }^{3} \mathrm{H}-{ }^{3} \mathrm{He}$ technique indicates an increase in the age of groundwater from $<1$ to $\sim 5 \mathrm{yr}$ at the same location (22). Between 15 and $20 \mathrm{~m}$ depth at site $\mathrm{F}$, the concentration of As increases rapidly to $200 \mu \mathrm{g} \mathrm{L}^{-1}$ and the age of groundwater increases by several decades to about 30 years. 


\section{Sample Collection}

A preliminary survey of the area was conducted in January 2005. A single well was drilled using the traditional "sludger" method and a series of groundwater and sediment samples were collected to a depth of $21 \mathrm{~m}$ using the needle-sampler (18). The diffuse spectral reflectance of the cuttings collected every $1.5 \mathrm{~m}$ was measured minutes after collection in the field to indicate the Fe speciation in the solid phase (21).

The samples used for the long-term incubations were collected in April 2005 from a new well within $2 \mathrm{~m}$ of the first profile. The needle sampler was used to obtain slurry samples from three depths: 5,12 and $38 \mathrm{~m}$. The starting material from each depth consisted of groundwater and sediment contained in two needle sampler tubes collected within $0.3 \mathrm{~m}$ of each other vertically. Preferential uptake of groundwater relative to sediment with the needle-sampler increased the porosity of the collected slurries. The porosity of sandy aquifers typically varies between 0.2 and 0.3 in the study area, while the material collected by the needle sampler had a porosity ranging from 0.7 to 0.8 . The collected sediment may also have been biased towards the finer fraction because the coarsest particles are excluded by the entry holes of the needle, which are less than $1 \mathrm{~mm}$ in diameter (18).

Before sampling, each needle-sampler tube was flushed with $\mathrm{N}_{2}$ and then evacuated to $<300$ mbar. To minimize $\mathrm{O}_{2}$ exposure, the headspace of each tube was also flushed with $\mathrm{N}_{2}$ immediately after collection. Aliquots of the collected groundwater were gently pressurefiltered in the field, also under $\mathrm{N}_{2}$. The needle-sampler tubes were then stored in plastic, $\mathrm{N}_{2-}$ flushed, air-tight anaerobic boxes (Becton-Dickinson) containing pouches that generate $\mathrm{H}_{2}$ and consume $\mathrm{O}_{2}$ with a catalyst. Three days after collection, the needle-sampler tubes were transferred to an anaerobic chamber (Coy Laboratories) where they remained for the duration of the experiment. The chamber was kept under a $\mathrm{N}_{2}$ atmosphere containing $1-2 \% \mathrm{H}_{2}$.

\section{Amendments}

The two needle sample slurries of roughly equal proportion from each depth were combined, homogenized and divided into five 60-mL amber glass bottles in the anaerobic chamber 17 days after collection (Supporting Information). Each microcosm bottle contained between 8 and $15 \mathrm{~mL}$ of groundwater and 5-11 $\mathrm{g}$ of sediment. The amendments could not be replicated because of the limited quantities of sediment and groundwater that were collected. The sample bottles were sealed with a butyl rubber stopper and an aluminum crimp. The bottles were gently agitated over the next 11 months and kept at room temperature. To minimize the potential effect of $\mathrm{H}_{2}$ contained in the anaerobic chamber on the incubations, the bottles were flushed with ultra-high purity $\mathrm{N}_{2}$ for several minutes after every sampling. The porosity of the different slurries was gradually reduced from an initial range of $0.6-0.9$ to a final $0.4-0.8$ by sampling water 7 times over the course of the experiment.

The slurries from each depth were treated in three different ways: without amendment, with the addition of acetate, and with periodic, small oxygen additions, hereafter referred to as unamended, acetate and oxygen incubations. The acetate addition ( $14 \mu$ mole per sample, which corresponds to $\sim 2 \mu$ mole $\mathrm{g}^{-1}$ sediment or $\sim 1.5 \mu$ mole $\mathrm{L}^{-1}$ groundwater) supplied enough electron donors to potentially reduce approximately $10 \%$ of the acid-leachable Fe present in the sediment. The oxygen additions occurred at each sampling point by adding approximately $1.2 \mathrm{~mL}$ of air to the $60 \mathrm{~mL}$ bottles (i.e. $10.3 \mu$ mole of $\mathrm{O}_{2}$, equivalent to $\sim 0.21 \mathrm{mg} \mathrm{O}_{2} \mathrm{~L}^{-1}$ groundwater). The oxygen addition could in principle oxidize $18 \mu \mathrm{g}$ of Fe after each sampling, which would be sufficient to remove more than $1.5 \mathrm{mg} \mathrm{L}^{-1} \mathrm{Fe}$ from solution. In addition, two amendments (autoclaving and addition of antibiotics) were prepared in an attempt to inhibit microbial activity and distinguish between biotic and abiotic processes. The results are not 
reported as autoclaving dramatically altered the sediment geochemistry and the antibiotic mix was not effective in reducing microbial activity.

\section{Analyses}

Groundwater samples collected from each incubation on days 17, 23, 40, 99, 160, 252 and 340 provide a detailed time series of variations in the concentrations of dissolved constituents, including $\mathrm{As}, \mathrm{Fe}, \mathrm{Mn}, \mathrm{S}, \mathrm{P}$ and the major cations, $\mathrm{Na}, \mathrm{K}, \mathrm{Mg}$ and $\mathrm{Ca}$ (Supporting Information). Aliquots of $1.2 \mathrm{~mL}$ were drawn from the slurries, filtered through $0.45 \mu \mathrm{m}$ syringe filters, acidified to $1 \% \mathrm{HCl}$ (Optima) and analyzed by High-Resolution Inductively Coupled Plasma Mass Spectrometry (HR ICP-MS) (23).

Aquifer sediment was analyzed on day 17 after collection, when the slurries were divided into amendments, and again on day 340 at the completion of the experiment. Two extractions were used to assess the availability of As in the solid phase. A $1 \mathrm{M}$ phosphate solution was used to estimate the amount of adsorbed As (24). A hot $1.2 \mathrm{M} \mathrm{HCl}$ solution was used to release As more tightly bound within amorphous Fe minerals (25). The extracts were analyzed for As using HR ICP-MS (23). Iron speciation of the $\mathrm{HCl}$ leachates were quantified on day 17 and day 340 using the ferrozine method (21). The abundance of organic substrate in each amendment was not assessed.

\section{Results Site Profile}

Dissolved As concentrations generally increased with depth from 20 to $100 \mu \mathrm{g} \mathrm{L}^{-1}$ in grey aquifers at the study site, although there is considerable variability between some closely spaced samples (Figure 1). Detectable levels of dissolved Fe and Mn indicate that groundwater was suboxic over the entire depth range (Supporting Information). The profile of sediment reflectance documents the increasingly reduced state of the aquifer as a function of depth and is consistent with a rise from 0.6 to 0.8 in the proportion of $\mathrm{Fe}$ (II) to total $\mathrm{Fe}$ in the sediment leachates. The concentration of P-extractable As in the sediment was highly variable in the upper $15 \mathrm{~m}\left(0.1-2.7 \mathrm{mg} \mathrm{kg}^{-1}\right)$. Two samples from three depths were used for the incubations. Differences in As concentrations between samples collected $0.3 \mathrm{~m}$ apart were small and initially averaged 40,72 and $88 \mu \mathrm{g} \mathrm{L}^{-1}$ in the dissolved phase and $0.5,1.4$ and $0.3 \mathrm{mg} \mathrm{kg}^{-1} \mathrm{P}$-extractable As in the sediment at 5, 12, and $38 \mathrm{~m}$ depth, respectively. Dissolved Fe concentrations were more variable for samples collected $0.3 \mathrm{~m}$ apart and ranged from 0.1 to $0.9 \mathrm{mg} \mathrm{L}^{-1}$ (Supporting Information).

\section{Iron}

Concentrations of dissolved Fe declined from an average of 0.3 to $0.1 \mathrm{mg} \mathrm{L}^{-1}$ and 0.8 to 0.3 $\mathrm{mg} \mathrm{L}^{-1}$ at 5 and $12 \mathrm{~m}$ depth, respectively, between the time of collection and day 17 when slurries from nearby depths were combined in the laboratory (Supporting Information). Over the same period, dissolved Fe concentrations in material from $38 \mathrm{~m}$ depth increased from 0.5 to $1.3 \mathrm{mg} \mathrm{L}^{-1}$. These early variations are small compared to subsequent 10 to 85 -fold increases in dissolved Fe concentrations for all unamended and acetate incubations until day 252, after which an almost equally large loss of Fe was observed on day 340 in the majority of samples (Figure 2). Over $90 \%$ of the total Fe released occurred after day 99 of the incubations. The proportion of $\mathrm{Fe}$ (II) to total $\mathrm{Fe}$ in the acid leachates remained nearly unchanged for the anoxic samples (with the exception of the unamended sample from $12 \mathrm{~m}$ depth for which the $\mathrm{Fe}$ (II)/ $\mathrm{Fe}$ ratio decreased from 0.7 to 0.5 ). After day 40, the oxygen addition maintained dissolved $\mathrm{Fe}$ concentrations below the detection limit of $0.1 \mathrm{mg} \mathrm{L}^{-1}$ at all three depths (with exception for the sample on day 252 at $12 \mathrm{~m}$ that measured $0.25 \mathrm{mg} \mathrm{L}^{-1}$ ). The leachable $\mathrm{Fe}(\mathrm{II}) / \mathrm{Fe}$ ratio in the sediment decreased from $0.6-0.8$ to $0.4-0.5$ in the incubations amended with oxygen. 


\section{Arsenic}

From the time of collection to day 17, the concentration of dissolved As declined from 40 to $28 \mu \mathrm{g} \mathrm{L}^{-1}$ and 72 to $38 \mu \mathrm{g} \mathrm{L}^{-1}$ in the slurries from 5 and $12 \mathrm{~m}$ depth and increased from 88 to $114 \mu \mathrm{g} \mathrm{L}^{-1}$ at $38 \mathrm{~m}$ depth. Dissolved As then gradually increased to $50-90 \mu \mathrm{g} \mathrm{L}^{-1}$ in the unamended and acetate samples from 5 and $12 \mathrm{~m}$ depth (Figure 2). At $38 \mathrm{~m}$, the amended and acetate samples showed no systematic trend or slightly decreased. The loss of dissolved $\mathrm{Fe}$ on day 340 was accompanied by a decrease in dissolved As in the unamended incubation from 5 $\mathrm{m}$ and in the acetate incubation from $12 \mathrm{~m}$. There was no systematic difference in As concentrations between the unamended and acetate incubations at $5 \mathrm{~m}$, while at $12 \mathrm{~m}$ the acetate amendment roughly doubled the amount of As released. After day 99 of incubation, the oxygen additions maintained dissolved As concentrations $<6 \mu \mathrm{g} \mathrm{L}^{-1}$ at all depths.

The concentration of P-extractable As in the sediment was determined on day 17 and 340; HClextractable As was determined only on day 340 (Supporting Information). At $5 \mathrm{~m}$, the Pextractable As concentration remained steady at $0.5 \mathrm{mg} \mathrm{kg}^{-1}$. Samples from $12 \mathrm{~m}$ had the highest level of P-extractable As of $1.4 \mathrm{mg} \mathrm{kg}^{-1}$, which decreased to about $0.6 \mathrm{mg} \mathrm{kg}^{-1}$ at the end of the experiment. At $38 \mathrm{~m}$, the P-extractable fraction decreased slightly from 0.30 to 0.24 $\mathrm{mg} \mathrm{kg}^{-1}$ between day 17 and 340. The observed decreases in P-extractable As concentrations in the solid phase can not be explained by the measured releases of As to groundwater because the releases are equivalent to only $2-6 \%$ of the total present in P-extractable form. The $\mathrm{HCl}-$ extractable As concentration in the solid phase at the end of the experiment was comparable at the three depths $\left(1.3-1.5 \mathrm{mg} \mathrm{kg}^{-1}\right)$.

\section{Sulfur}

Dissolved S concentrations in the unamended and acetate incubations show no discernable trend. In contrast, dissolved $\mathrm{S}$ increased in the oxygen incubations to maximum concentrations of $2.2,3.8$ and $53.5 \mathrm{mg} \mathrm{L}^{-1}$ in the 5,12 and $38 \mathrm{~m}$ samples, respectively.

\section{Discussion}

\section{Iron Release and Precipitation}

Few, if any, studies have document the release of Fe from natural aquifer solids to actual groundwater under anoxic conditions and over an extended period of time. In comparison to subsequent changes, the variations in dissolved $\mathrm{Fe}$ concentrations in slurries between the time of collection and the onset of the actual incubations on day 17 day were modest, suggesting that the system was not excessively perturbed by sampling, transport, and manipulation. By day 99 , oxygen additions had already drastically decreased dissolved Fe concentrations to $<0.1$ $\mathrm{mg} \mathrm{L}^{-1}$ due to oxidation and precipitation of $\mathrm{Fe}$ (II) initially present in the groundwater. The higher dissolved $\mathrm{Fe}$ concentrations maintained throughout for other incubations suggest that anoxic conditions were successfully maintained in the absence of oxygen additions.

It is likely that the dilution of aquifer particles in ambient groundwater increased the exposure of surface sites available for adsorption, and this may be the reason for the $30 \%$ reduction in dissolved Fe observed at 5 and $12 \mathrm{~m}$ depth between days 0 and 17. The increase in dissolved $\mathrm{Fe}$ at $38 \mathrm{~m}$ depth cannot be similarly explained, but there are other indications that the geochemistry of the aquifer material was different at that depth. The increase in dissolved S (most likely in the form of sulfate) concentrations observed in all oxygen incubations was much greater at $38 \mathrm{~m}$ depth than at 5 or $12 \mathrm{~m}$ (Supporting Information). This suggests that aquifer material from $38 \mathrm{~m}$ depth, and not in the shallow material, contained a considerable proportion of reduced and labile $S$, which has been observed in Bangladesh aquifer material (14). A simple calculation shows that labile $\mathrm{S}$ could be bound to an equivalent of $0.8 \%$ of the total acidleachable Fe at $38 \mathrm{~m}$ depth. 
The large release of $\mathrm{Fe}$ observed in the six incubations under anaerobic conditions between days 99 and 252 suggests a significant departure from initial conditions in the aquifer. The enhanced release may reflect that new and/or more Fe(III) surface sites became available for microbial reduction because of dilution of initially more tightly packed particles, as well as a potential thinning of the diffuse-boundary layer caused by gentle agitation of the slurries. Laboratory studies using model solids have shown that $\mathrm{Fe}$ (II) is not necessarily released during the early stages of microbial $\mathrm{Fe}(\mathrm{III})$ reduction, but can instead adsorb onto the oxide surface or form secondary minerals (26-28). Re-adsorption of Fe(II) on newly available sites, until they became saturated, is therefore a plausible explanation for the observed delay in the large increase in dissolved $\mathrm{Fe}$ (II) concentrations until after day 160 of the incubations (Figure 2).

The maximum Fe concentrations reached during the anoxic incubations are higher than typically observed in Bangladesh groundwater, but similar levels have been observed in Vietnam (29). The rise in Fe concentrations corresponds to a release of $0.2-50 \mathrm{mg} \mathrm{Fe} \mathrm{kg}^{-1}$ of sediment and corresponds to only 0.01 to $0.8 \%$ of $\mathrm{HCl}$-extractable Fe. The limited impact of the acetate amendment suggests that organic substrate availability does not limit microbial Fe reduction in these shallow aquifers (30). We cannot exclude the possibility that the observed Fe releases were driven by abiotic desorption rather than microbial Fe reduction $(5,12,28$, 31-33). In that case, however, a gradual release over the entire course of the experiment towards a new steady-state might have been expected instead of a delay followed by an increasing release of Fe.

The large drop in dissolved Fe concentrations for 5 out of 6 anoxic incubations between days 252 and 340 suggests that saturation with respect to a solid phase had been reached (27). Geochemical calculations were performed using Geochemist's Workbench (Rockware, Inc.) with the Lawrence Livermore National Laboratories combined database with published alterations $(34,35)$. Analysis of Fe precipitation by day 340 was conducted using concentrations of all elements measured in the unamended samples at day 252 (Supporting Information).

Solubility calculations and a concurrent 2 to $40 \mu \mathrm{g} \mathrm{L} \mathrm{L}^{-1}$ reduction in dissolved P concentrations suggest the formation of Fe-sulfides and Fe-phosphate minerals, such as pyrite and vivianite. It is noteworthy that the decline in dissolved As in response to significant Fe precipitation was modest, possibly due to competition with other groundwater constituents for binding sites, particularly on Fe sulfide minerals (36), and limited co-precipitation.

\section{Initial As Adsorption}

In the case of As, we use a formulation equivalent to a Langmuir isotherm to estimate the potential effect of increasing the availability of surface site due to dilution of the particles in the slurries upon collection. Adsorption of As is assumed to be controlled by a simple massaction law of the form: $\mathrm{S}+\mathrm{A}=\mathrm{SA}$ and an adsorption coefficient $\mathrm{K}_{\mathrm{ads}}=[\mathrm{SA}] /([\mathrm{S}][\mathrm{A}])$, where $\mathrm{S}$ represents the concentration of surface sites in the slurry and $\mathrm{A}$ is the concentration of dissolved As. The concentration of dissolved As (A) was measured in the sample filtered in the field right after collection and 17 days later; the concentration of P-extractable As is used as a proxy for adsorbed As (SA). For each of the three depths, the change in available surface sites, $\mathrm{S}$, was calculated assuming equilibrium at collection and that the change in dissolved As from day 0 to day 17 was entirely due to adsorption (Supporting Information). Using this model, the decline in As concentrations observed in slurries from 5 and $12 \mathrm{~m}$ depth could be explained entirely by a 50 and $90 \%$ increase, respectively, in surface sites (as in the case of Fe, no effect of dilution was observed in slurries from $38 \mathrm{~m}$ depth for As).

\section{Implications of Observed Arsenic Release}

The noticeable impact of oxygen additions on the incubations of aquifer material from all three depths confirms that the formation of fresh Fe(III) adsorption sites is sufficient to significantly 
limit the release of As. Anoxia therefore appears to be a prerequisite for accumulating As in groundwater of Bangladesh. This does not mean that anoxia alone is sufficient to cause As mobilization or that releases of As and Fe to groundwater are necessarily coupled. Indeed, the time course of the anoxic incubations provides new evidence of decoupling between As and Fe mobilization. The release of As at 5 and $12 \mathrm{~m}$ was evident by day 40, while Fe release did not begin until day 99 and rapidly increased after day 160. The lack of Fe release could be due to Fe adsorption and secondary mineral formation, as described above. The large release of Fe to groundwater by day 252, however, did not cause a concomitant increase in As concentrations. This decoupling could be related to the formation of various secondary Fe minerals, including vivianite and magnetite, which can incorporate As into the new minerals $(17,28)$. Alternatively As may not be distributed uniformly within Fe oxyhydroxide surfaces (10). In either case, the observations suggest that the processes regulating As and Fe release may have little in common once an aquifer becomes anoxic.

Average rates of As mobilization were calculated for each anoxic incubation. The rate of As release for each sample was calculated beginning with day 23 , six days after amendment. The entire 340 days were considered for the acetate incubation at $5 \mathrm{~m}$. Only the releases until day 252 were included for the unamended incubation at the $5 \mathrm{~m}$ depth and both anoxic incubations from $12 \mathrm{~m}$ and $38 \mathrm{~m}$ due to the large loss of $\mathrm{Fe}$ by this time and the uncertain influence this had on As release (Figure 3). The amount of As released was calculated by determining the change in mass of dissolved As between each sampling and normalized this to the total mass of sediment. Rates of release were determined by least-squares regression; the uncertainty is listed as two times the standard deviation $(\sigma)$ of the slope. The combined rate of As release was $21 \pm 4 \mu \mathrm{g} \mathrm{As} \mathrm{kg}^{-1}$ sediment per year $\left(\mathrm{r}^{2}=0.91, \mathrm{n}=9\right)$ for the two anoxic incubations from 5 depth; the calculated rates were not statistically different between the types of amendment. At $12 \mathrm{~m}$, the acetate addition increased the rate of As release nearly 4-fold from $23 \pm 6 \mu \mathrm{g}$ As $\mathrm{kg}^{-1} \mathrm{yr}^{-1}\left(\mathrm{r}^{2}=0.93, \mathrm{n}=4\right)$ to $82 \pm 18 \mu \mathrm{g} \mathrm{kg}^{-1} \mathrm{yr}^{-1}\left(\mathrm{r}^{2}=0.95, \mathrm{n}=4\right)$ for the unamended and acetate incubations, respectively. The $5 \mathrm{~m}$ samples may have a higher natural abundance of organic substrate, due to their younger age and closer proximity to surface organic inputs, thus rendering the acetate addition superfluous $(14,37)$. The combined set of observations indicates that the process of As mobilization in Bangladesh is potentially microbially mediated, although not necessarily limited by the availability of organic substrate.

The incubations unambiguously demonstrate that As is not necessarily released at higher rates in shallow grey aquifers of Bangladesh where dissolved As concentrations are elevated.

Whereas groundwater As concentrations increased with depth at the sampling site (Figure 1), As release was only observed in aquifer material from 5 and $12 \mathrm{~m}$ depth. The sample from 38 $\mathrm{m}$ had the highest initial As concentrations in groundwater and yet no release was observed, although the release of Fe was comparable at all depths. The low level of P-extractable As contained in aquifer material from $38 \mathrm{~m}$ suggests that As release was limited by the lack of a sufficient pool of mobilizible As in the solid phase. Elevated groundwater As concentrations observed at $38 \mathrm{~m}$ and the absence of As release therefore probably indicates transport of As released at shallower depths, as suggested previously $(5,38)$. Re-adsorption of As released elsewhere at $38 \mathrm{~m}$ depth may also have been inhibited by the lower adsorption capacity of Fesulfide minerals, whose presence is suggested by the effect of the oxygen amendment (36). According to the rates of As release measured at 5 and $12 \mathrm{~m} \mathrm{depth}$, an initial pool of $\sim 10 \mathrm{mg}$ $\mathrm{kg}^{-1}$ mobilizible As $(2,39)$ could be lost from an aquifer due to groundwater flow in as little as 1,000 years assuming no replenishment of transported As. Such a flushing mechanism has previously been invoked to explain low groundwater As concentrations in older grey sediment $(19,37)$, 


\section{Re-Interpreting Spatial Patterns of As in Groundwater}

Estimating the increase in dissolved As in the aquifer corresponding to the measured release rates requires consideration of the increased surface site availability as well as the increased porosity of the incubations. If we assume As mobilization is related to surface site availability, greater surface exposure to the groundwater should lead to more As release. We postulate here that adsorption and release are affected similarly by changes in surface site availability, and therefore assume that the measured rates of As release overestimate the rate of release in the aquifer by 50 to $90 \%$ (depending on depth), as determined from the observed As adsorption that occurred upon sample collection. This is partially offset by the lower porosity of aquifers which causes the release (as measured in ng As released per kg sediment) to have a greater affect on dissolved As concentrations than observed in the incubations. Considering these two competing effects, the observed release rates of As would be equivalent to increases in dissolved As of $110 \mu \mathrm{g} \mathrm{L}-1$ per year at $5 \mathrm{~m}$ and $90 \mu \mathrm{g} \mathrm{L}-1$ per year at $12 \mathrm{~m}$.

The observed rates suggest a relatively constant release of As from aquifer sediments; this however does not imply that dissolved As concentrations are necessarily increasing in the aquifer over time. Indeed, a recent study of a large number of wells in Araihazar has shown that dissolved As concentrations remained relatively constant over several years (40). Steadystate concentrations could reflect a balance between the release of As from grey aquifer solids and continuous replacement of groundwater with surface water that is initially low in As (22). The short time scale of As release does suggest that the distribution of As in shallow aquifers could change over time, particularly in a region like the present study area where irrigation pumping is probably drastically affected flow patterns (20).

A recent study in this region of Bangladesh provides evidence that the observed rise of As concentrations in groundwater over time indicated by these long-term incubations is realistic. Shallow groundwater was dated by the ${ }^{3} \mathrm{H}-{ }^{3} \mathrm{He}$ technique at a set of six nests of monitoring wells in the same general area of Araihazar (22). Whereas the age of groundwater increased with depth at all six sites, the rate of increase varied considerably from one site to the other most likely in response to variations in local recharge. Comparison of groundwater ages ranging from $<1$ to over 30 years with groundwater As concentrations of 1 to $520 \mu \mathrm{g} \mathrm{L}^{-1}$ measured in the same set of wells, however, results in a relationship that is fairly consistent across all sites and corresponds to a release rate of $19 \pm 2 \mu \mathrm{g} \mathrm{L}{ }^{-1}$ As per year. This entirely independent measure of the rate of As accumulation in groundwater is within a factor of 5 of the rates measured in the unamended incubations, after correction for the estimated effect of increased exposure of surface sites.

Our incubations of simultaneously collected Bangladesh sediment and groundwater over an extended period provide new evidence that the concentration of dissolved $\mathrm{Fe}$ in groundwater is not necessarily linked to the rate of reductive dissolution of Fe oxyhydroxides. This may be one reason why there is no simple relationship between concentrations of $\mathrm{Fe}$ and As in anoxic groundwater $(2,5,10,21,41)$. The limited impact of acetate on incubations of natural aquifer material suggests that the release of both $\mathrm{Fe}$ and As is not necessarily limited by the supply of organic substrate. Flow patterns and groundwater age may therefore play a dominant role in setting the highly variable distribution of As in shallow groundwater of Bangladesh.

\section{Supplementary Material}

Refer to Web version on PubMed Central for supplementary material. 


\section{Acknowledgements}

Columbia University and the University of Dhaka's research in Araihazar has been supported since 2000 by NIEHS Superfund Basic Research Program grant NIEHS 1 P42 ES10349. This experiment was supported by NSF grant EAR 04-33886 and builds on continuing work in Bangladesh conducted with our colleagues Yan Zheng (Queens College/ CUNY and LDEO) and Martin Stute (Barnard College and LDEO). The paper benefited from detailed comments provided by three anonymous reviewers. This is Lamont-Doherty Earth Observatory contribution number XXXX.

\section{Literature Cited}

1. Dhar RK, Biswas BK, Samanta G, Mandal BK, Chakraborti D, Roy S, Jafar A, Islam A, Ara G, Kabir S, Khan AW, Ahmed SA, Hadi SA. Groundwater arsenic calamity in Bangladesh. Curr. Sci 1997;73:48-59.

2. BGS/DPHE “Arsenic Contamination of Groundwater in Bangladesh, Final Report.,”. British Geological Survey, Dept. of Public Health Engineering; 2001.

3. Lovley DR. Microbial Fe(III) reduction in subsurface environments. Fems Microbiology Reviews 1997;20:305-313.

4. Nickson R, McArthur J, Burgess W, Ahmed KM, Ravenscroft P, Rahman M. Arsenic poisoning of Bangladesh groundwater. Nature 1998;395:338-338. [PubMed: 9759723]

5. Polizzotto ML, Harvey CF, Sutton SR, Fendorf S. Processes conducive to the release and transport of arsenic into aquifers of Bangladesh. Proc. Natl. Acad. Sci. U. S. A 2005;102:18819-18823. [PubMed: 16357194]

6. Ahmann D, Krumholz LR, Hemond HF, Lovley DR, Morel FMM. Microbial mobilization of arsenic from sediments of the Aberjona Watershed. Environ. Sci. Technol 1997;31:2923-2930.

7. Jones CA, Langner HW, Anderson K, McDermott TR, Inskeep WP. Rates of microbially mediated arsenate reduction and solubilization. Soil Sci. Soc. Am. J 2000;64:600-608.

8. Zobrist J, Dowdle PR, Davis JA, Oremland RS. Mobilization of arsenite by dissimilatory reduction of adsorbed arsenate. Environ. Sci. Technol 2000;34:4747-4753.

9. Benner SG, Hansel CM, Wielinga BW, Barber TM, Fendorf S. Reductive dissolution and biomineralization of iron hydroxide under dynamic flow conditions. Environ. Sci. Technol 2002;36:1705-1711. [PubMed: 11993867]

10. Van Geen A, Rose J, Thoral S, Garnier JM, Zheng Y, Bottero JY. Decoupling of As and Fe release to Bangladesh groundwater under reducing conditions. Part II: Evidence from sediment incubations. Geochim. Cosmochim. Acta 2004;68:3475-3486.

11. Bostick BC, Fendorf S, Manning BA. Arsenite adsorption on galena ( $\mathrm{PbS})$ and sphalerite ( $\mathrm{ZnS})$. Geochim. Cosmochim. Acta 2003;67:895-907.

12. Dixit S, Hering JG. Comparison of $\operatorname{arsenic}(\mathrm{V})$ and arsenic(III) sorption onto iron oxide minerals: Implications for arsenic mobility. Environ. Sci. Technol 2003;37:4182-4189. [PubMed: 14524451]

13. Oremland RS, Stolz JF. The ecology of arsenic. Science 2003;300:939-944. [PubMed: 12738852]

14. Harvey CF, Swartz CH, Badruzzaman ABM, Keon-Blute N, Yu W, Ali MA, Jay J, Beckie R, Niedan V, Brabander D, Oates PM, Ashfaque KN, Islam S, Hemond HF, Ahmed MF. Arsenic mobility and groundwater extraction in Bangladesh. Science 2002;298:1602-1606. [PubMed: 12446905]

15. Islam FS, Gault AG, Boothman C, Polya DA, Charnock JM, Chatterjee D, Lloyd JR. Role of metalreducing bacteria in arsenic release from Bengal delta sediments. Nature 2004;430:68-71. [PubMed: 15229598]

16. Klump S, Kipfer R, Cirpka OA, Harvey CF, Brennwald MS, Ashfaque KN, Badruzzaman ABM, Hug SJ, Imboden DM. Groundwater dynamics and arsenic mobilization in Bangladesh assessed using noble gases and tritium. Environ. Sci. Technol 2006;40:243-250. [PubMed: 16433358]

17. Gault AG, Islam FS, Polya DA, Charnock JM, Boothman C, Chatterjee D, Lloyd JR. Microcosm depth profiles of arsenic release in a shallow aquifer, West Bengal. Mineralogical Magazine 2005;69:855-863.

18. Van Geen A, Protus T, Cheng Z, Horneman A, Seddique AA, Hoque MA, Ahmed KM. Testing groundwater for arsenic in Bangladesh before installing a well. Environ. Sci. Technol 2004;38:67836789. [PubMed: 15669339] 
19. Zheng Y, van Geen A, Stute M, Dhar R, Mo Z, Cheng Z, Horneman A, Gavrieli I, Simpson HJ, Versteeg R, Steckler M, Grazioli-Venier A, Goodbred S, Shahnewaz M, Shamsudduha M, Hoque MA, Ahmed KM. Geochemical and hydrogeological contrasts between shallow and deeper aquifers in two villages of Araihazar, Bangladesh: Implications for deeper aquifers as drinking water sources. Geochim. Cosmochim. Acta 2005;69:5203-5218.

20. van Geen A, Zheng Y, Cheng Z, He Y, Dhar RK, Garnier JM, Rose J, Seddique A, Hoque MA, Ahmed KM. Impact of irrigating rice paddies with groundwater containing arsenic in Bangladesh. Sci. Total Environ 2006;367:769-777. [PubMed: 16730050]

21. Horneman A, Van Geen A, Kent DV, Mathe PE, Zheng Y, Dhar RK, O'Connell S, Hoque MA, Aziz Z, Shamsudduha M, Seddique AA, Ahmed KM. Decoupling of As and Fe release to Bangladesh groundwater under reducing conditions. Part I: Evidence from sediment profiles. Geochim. Cosmochim. Acta 2004;68:3459-3473.

22. Stute M, Zheng Y, Schlosser P, Horneman A. Increase in arsenic concentrations with groundwater age in shallow Bangladesh aquifers. Water Resour. Res. accepted, in press

23. Cheng Z, Zheng Y, Mortlock R, van Geen A. Rapid multi-element analysis of groundwater by highresolution inductively coupled plasma mass spectrometry. Analytical and Bioanalytical Chemistry 2004;379:512-518. [PubMed: 15098084]

24. Jung HB, Zheng Y. Enhanced recovery of arsenite sorbed onto synthetic oxides by L-ascorbic acid addition to phosphate solution: calibrating a sequential leaching method for the speciation analysis of arsenic in natural samples. Water Res 2006;40:2168-2180. [PubMed: 16725174]

25. Keon NE, Swartz CH, Brabander DJ, Harvey C, Hemond HF. Validation of an arsenic sequential extraction method for evaluating mobility in sediments. Environ. Sci. Technol 2001;35:2778-2784. [PubMed: 11452609]

26. Roden EE. Analysis of long-term bacterial vs. chemical Fe(III) oxide reduction kinetics. Geochim. Cosmochim. Acta 2004;68:3205-3216.

27. Fredrickson JK, Zachara JM, Kennedy DW, Dong HL, Onstott TC, Hinman NW, Li SM. Biogenic iron mineralization accompanying the dissimilatory reduction of hydrous ferric oxide by a groundwater bacterium. Geochim. Cosmochim. Acta 1998;62:3239-3257.

28. Coker VS, Gault AG, Pearce CI, van der Laan G, Telling ND, Charnock JM, Polya DA, Lloyd JR. XAS and XMCD evidence for species-dependent partitioning of arsenic during microbial reduction of ferrihydrite to magnetite. Environ. Sci. Technol 2006;40:7745-7750. [PubMed: 17256522]

29. Berg M, Tran HC, Nguyen TC, Pham HV, Schertenleib R, Giger W. Arsenic contamination of groundwater and drinking waiter in Vietnam: A human health threat. Environ. Sci. Technol 2001;35:2621-2626. [PubMed: 11452583]

30. Rowland HAL, Polya DA, Lloyd JR, Pancost RD. Characterisation of organic matter in a shallow, reducing, arsenic-rich aquifer, West Bengal. Org. Geochem 2006;37:1101-1114.

31. Polizzotto ML, Harvey CF, Li GC, Badruzzman B, Ali A, Newville M, Sutton S, Fendorf S. Solidphases and desorption processes of arsenic within Bangladesh sediments. Chem. Geol 2006;228:97111.

32. Herbel M, Fendorf S. Biogeochemical processes controlling the speciation and transport of arsenic within iron coated sands. Chem. Geol 2006;228:16-32.

33. Smedley PL, Kinniburgh DG. A review of the source, behaviour and distribution of arsenic in natural waters. Applied Geochemistry 2002;17:517-568.

34. Delany, JM.; Lundeen, SR. “The LLNL thermochemical database,”. 1990.

35. O'Day PA, Vlassopoulos D, Root R, Rivera N. The influence of sulfur and iron on dissolved arsenic concentrations in the shallow subsurface under changing redox conditions. Proc. Natl. Acad. Sci. U. S. A 2004;101:13703-13708. [PubMed: 15356340]

36. Bostick BC, Chen C, Fendorf S. Arsenite retention mechanisms within estuarine sediments of Pescadero, CA. Environ. Sci. Technol 2004;38:3299-3304. [PubMed: 15260327]

37. McArthur JM, Banerjee DM, Hudson-Edwards KA, Mishra R, Purohit R, Ravenscroft P, Cronin A, Howarth RJ, Chatterjee A, Talukder T, Lowry D, Houghton S, Chadha DK. Natural organic matter in sedimentary basins and its relation to arsenic in anoxic ground water: the example of West Bengal and its worldwide implications. Applied Geochemistry 2004;19:1255-1293. 
38. Harvey CF, Ashfaque KN, Yu W, Badruzzaman ABM, Ali MA, Oates PM, Michael HA, Neumann $\mathrm{RB}$, Beckie R, Islam S, Ahmed MF. Groundwater dynamics and arsenic contamination in Bangladesh. Chem. Geol 2006;228:112-136.

39. Meharg AA, Scrimgeour C, Hossain SA, Fuller K, Cruickshank K, Williams PN, Kinniburgh DG. Codeposition of organic carbon and arsenic in Bengal Delta aquifers. Environ. Sci. Technol 2006;40:4928-4935. [PubMed: 16955888]

40. Cheng Z, Van Geen A, Seddique AA, Ahmed KM. Limited temporal variability of arsenic concentrations in 20 wells monitored for 3 years in Araihazar, Bangladesh. Environ. Sci. Technol 2005;39:4759-4766. [PubMed: 16053073]

41. Swartz CH, Blute NK, Badruzzman B, Ali A, Brabander D, Jay J, Besancon J, Islam S, Hemond HF, Harvey CF. Mobility of arsenic in a Bangladesh aquifer: Inferences from geochemical profiles, leaching data, and mineralogical characterization. Geochim. Cosmochim. Acta 2005;69:5159-5159. 


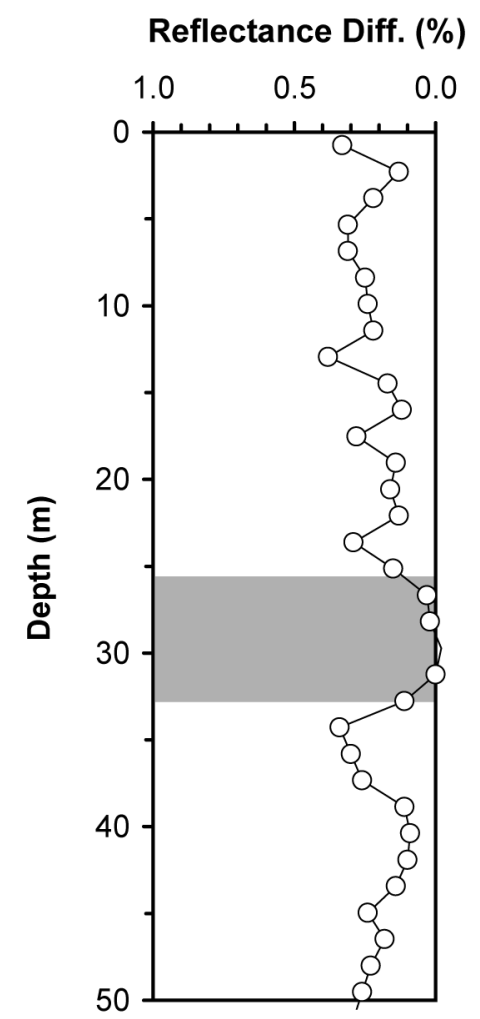

\section{Leachable $\mathrm{Fe}(\mathrm{II}) / \mathrm{Fe}$}

Dissolved As ( $\mu \mathrm{g} / \mathrm{L})$

P-extr. As (mg/kg)
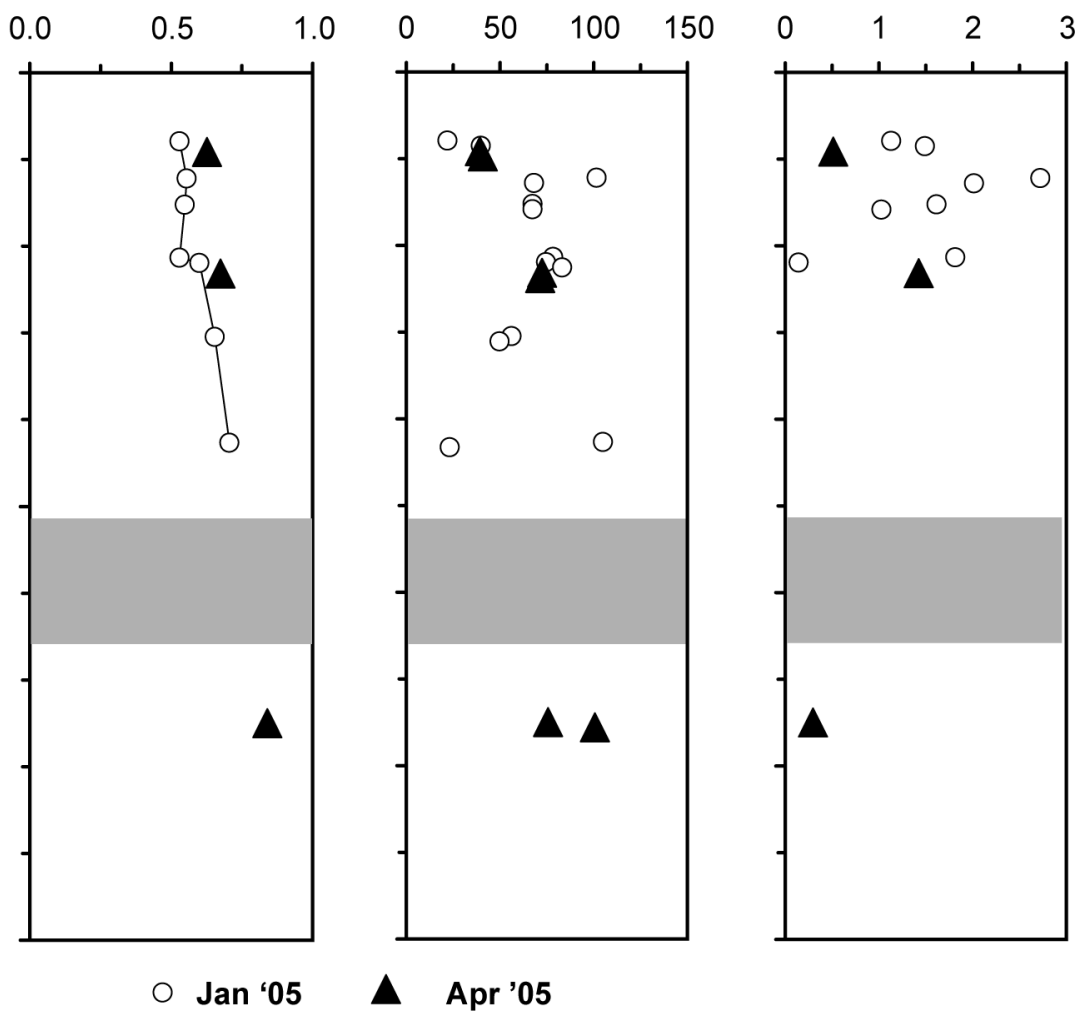

Figure 1.

Profiles of sediment and groundwater at the study site in Araihazar, Bangladesh: (a) difference in diffuse spectral reflectance at 530 and $520 \mathrm{~nm}$ measured on-site for cuttings recovered during drilling; (b) proportion of $\mathrm{Fe}(\mathrm{II})$ in the HCl-leachable Fe fraction of sediment samples; (c) dissolved As concentrations in groundwater; (d) concentration of P-extractable As in the sediment. With the exception of the cuttings used for reflectance measurements in January 2005, all sediment and groundwater samples were obtained with the needle-sampler in January (open circles) and April (black triangles) 2005. The grey shading indicates the extent of a thick clay layer encountered at the site. 

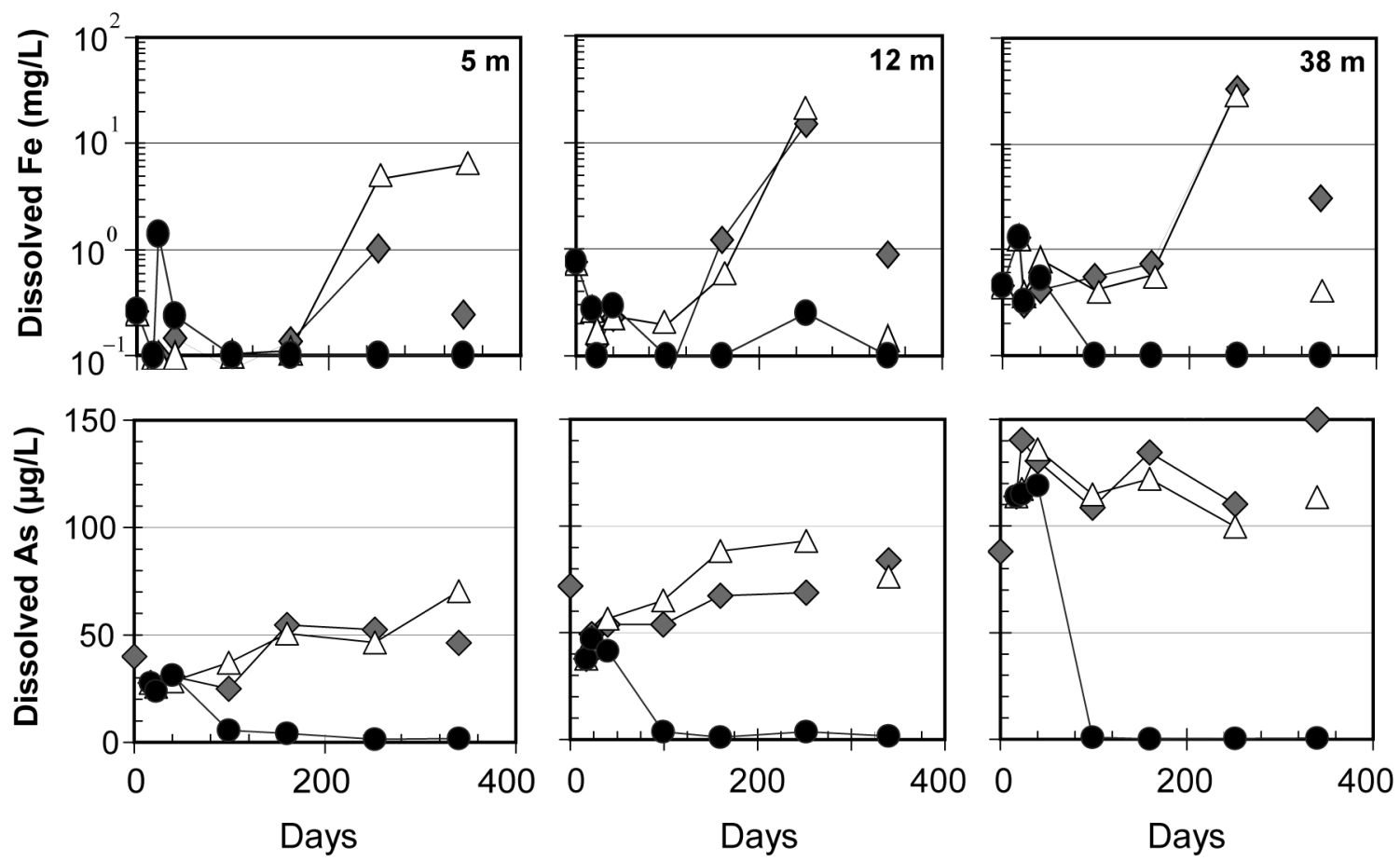

Unamended $\Delta$ Acetate $\bullet$ Oxygen

Figure 2.

Variations in dissolved Fe and As concentrations over the course of the 11-month long incubations of sediment and groundwater slurries collected in Bangladesh at three different depths in April 2005. Note the logarithmic scale for dissolved Fe. Disconnected symbols indicate samples exhibiting a large drop in dissolved Fe at the completion of the incubations. 

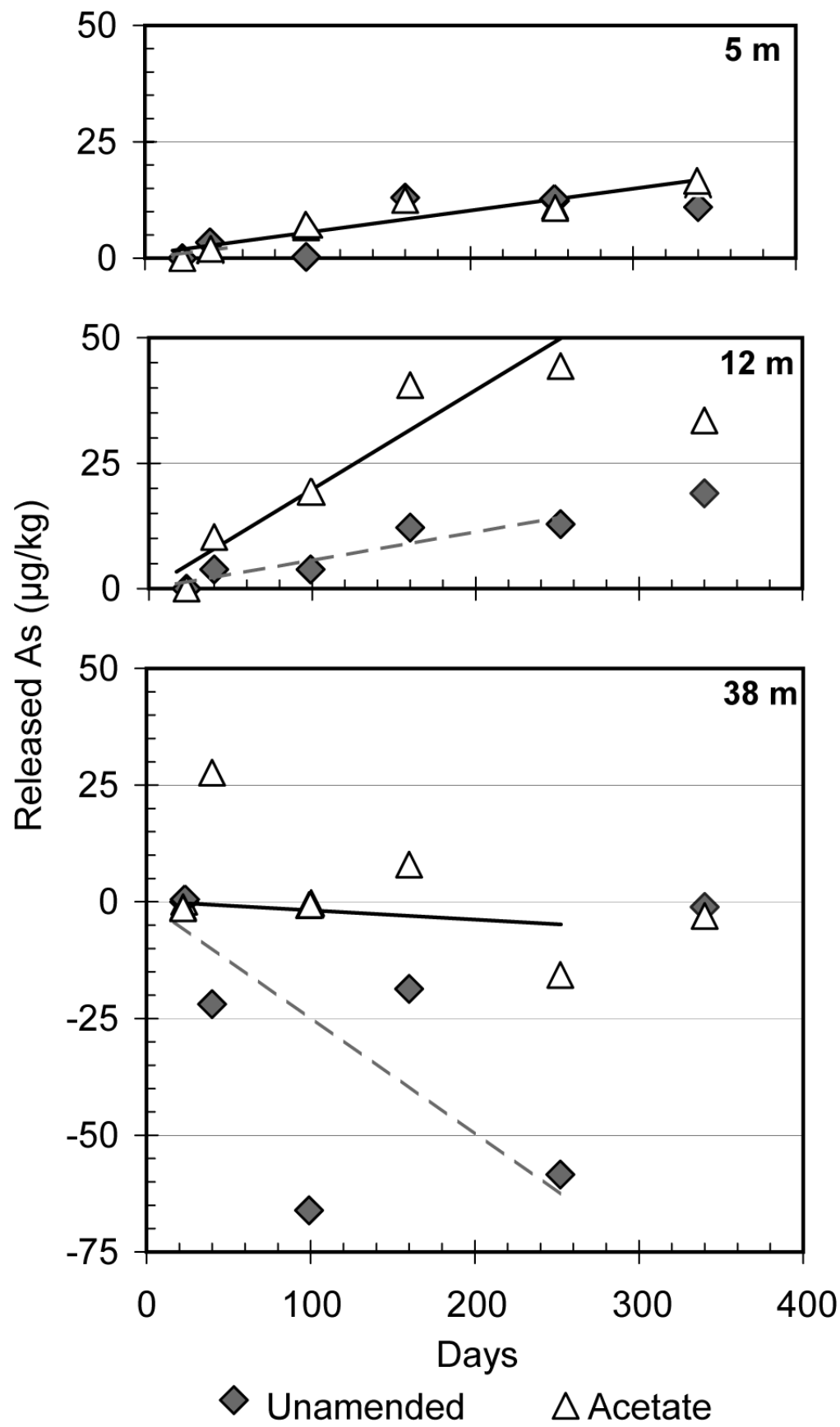

Figure 3.

Amount of As released to groundwater for anoxic incubations normalized to the quantity of sediment in each slurry of Bangladesh aquifer material. The rates of release were calculated by least-squares regression fit over the time span, as indicated by the regression lines. The regression for the $5 \mathrm{~m}$ depth combined the unamended and acetate incubations, while the regressions were calculated separately at $12 \mathrm{~m}$ and $38 \mathrm{~m}$. 